\title{
Estimates of covariance functions for growth of Anglo-Nubian goats
}

\section{José Ernandes Rufino de Sousa ${ }^{1}$, Martinho de Almeida e Silva ${ }^{2}$, José Lindenberg Rocha Sarmento $^{1}$, Wandrick Hauss de Sousa ${ }^{3}$, Maria do Socorro Medeiros de Souza ${ }^{1}$, Isabel Cristina Ferreira ${ }^{4}$}

\footnotetext{
${ }^{1}$ Campus Universitário Profa. Cinobelina Elvas/UFPI.

2 Escola de Veterinária/DZ/UFMG. Pesquisador do CNPq.

${ }^{3}$ Empresa Estadual de Pesquisa Agropecuária da Paraíba - EMEPA-PB.

${ }^{4}$ Universidade Federal de Uberlândia - UFU.
}

\begin{abstract}
It was used 4,313 weight records from birth to 196 days of age from 946 Anglo-nubiana breed goats, progenies from 43 sires and 279 dams, controlled in the period from 1980 to 2005, with the objective of estimating covariance functions and genetic parameters of animals by using random regression models. It was evaluated 12 random regression models, with degrees ranging from 1 to 7 for direct additive genetic and maternal and animal permanent environment effect and residual variance adjusted by using animal age ordinary polynomial of third order. Models were compared by using likelihood ratio test and by Bayesian information criterion of Schwarz and Akaike information criterion. The model selected based on Bayesian information criterion was the one that considered the maternal and direct additive genetic effect adjusted by a quadratic polynomial and the animal permanent environmental effect adjusted by a cubic polynomial (M334). Heritability estimates for direct effect were lower in the beginning and at the end of the studied period and maternal heritability estimates were higher at 196 days of age in comparison to the other growth phases. Genetic correlation ranged from moderate to high and they decreased as the distance between ages increased. Higher efficiency in selection for weight can be obtained by considering weights close to weaning, which is a period when the highest estimates of genetic variance and heritability are obtained.
\end{abstract}

Key Words: covariance function, genetic parameter, goat, Legendre polynomial

\section{Estimativas de funções de covariância para crescimento de caprinos anglo nubianos}

RESUMO - Foram utilizados 4.313 registros de pesos do nascimento aos 196 dias de idade de 946 animais da raça AngloNubiana, filhos de 43 reprodutores e 279 cabras, controlados no período de 1980 a 2005, com o objetivo de estimar funções de covariância e parâmetros genéticos dos animais por meio de modelos de regressão aleatória. Foram avaliados 12 modelos de regressão aleatória, com graus variando de 1 a 7 para os efeitos genéticos aditivo direto e materno e de ambiente permanente de animal e com variância residual ajustada por meio de um polinômio ordinário da idade dos animais de ordem 3. Os modelos foram comparados pelo teste de razão de verossimilhança e pelos critérios de informação de Akaike e o Bayesiano de Schwarz. O modelo escolhido com base no critério de informação Bayesiano foi o que considerou o efeito genético aditivo direto e materno ajustado por um polinômio quadrático e o efeito de ambiente permanente de animal ajustado por polinômio cúbico (M334). As estimativas de herdabilidade para o efeito direto foram menores no início e no final do período estudado e a herdabilidade materna foi maior, aos 196 dias de idade em comparação às demais fases de crescimento. As correlações genéticas variaram de moderadas a altas e diminuíram conforme o aumento da distância entre as idades. Maior eficiência na seleção para peso pode ser obtida considerando os pesos próximos à desmama, período em que as maiores estimativas de variância genética e herdabilidade foram obtidas.

Palavras-chave: caprino, função de covariância, parâmetro genético, polinômio de Legendre

\section{Introduction}

In Brazil, most goat herds (92\%) are located in the northeastern region and they are greatly influenced by Anglo Nubian breed, which was introduced in the country to genetically improve goat meat and milk production of native breeds by crosses among breeds and also for maintenance of the breed.

For meat type goat, weights recorded during the growth period of the animals in structured population are the main 
information source for genetic evaluations. The traits are classified as longitudinal since they represent measures of the same trait recorded during the growth period of the animals and they are analyzed by factorial models in which each observation is considered as a different trait producing similar window models or finite dimension model (Kirkpatrick et al., 1990).

Kirkpatrick \& Heckman (1989) described some advantages of the covariance function models in relation to multi-trait model which are the following: they allow to predict the covariance structure in any point of a continuous time scale, gives more flexibility in the use of measure recorded in any moment of the growth trajectory without the need of adjusting the record for standard age; they allow to obtain eigen values and eigen vectors that gives information about the direction in which the average curve has higher chance to be modified by selection, in function of higher genetic variance; they allow to estimate a continuous gradient selection function considering the effect of selection in all points of the growth curve, and finally, they allow to accurately predict the selection response.

The use of random regression on model longitudinal data is not recent in linear model analyses and it was introduced by Henderson Júnior (1982). Recently, several scientific papers have been using covariance functions by means of random regression models applied to animal genetic improvement (Sakaguti et al., 2003; Arango et al., 2004; Albuquerque \& Meyer, 2005; Santoro et al., 2005; Dias et al., 2006; Sousa et al., 2008).

The objective of this paper was to evaluate the use of covariance function analyses using random regression models in genetic evaluation of goat growth curve of Anglo-Nubian breed.

\section{Material and Methods}

Data of goat production traits of Anglo Nubian breed recorded from 1980 to 2005, from Fazenda Experimental Pendência, belonging to the Empresa Estadual de Pesquisa Agropecuária da Paraíba (EMEPA - PB) were used in the analyses. The farm is located in the municipality of Soledade, $7^{\circ} 8^{\prime} 18^{\prime \prime S}$ and 36²7'2"W, average altitude $546 \mathrm{~m}$. Based on Köppen classification, the region climate is classified as Bsh, a warm semi-arid climate with annual average temperature of $24^{\circ} \mathrm{C}$, relative humidity of $68 \%$, annual rain of $400 \mathrm{~mm}$, and with water deficit during almost all the year.

The animals were raised in a semi intensive breeding system on native and improved pasture paddocks and were supplementary fed corn and sorghum silages, maniçoba hay and cactus pear (Opuntia ficus-indica), a 14 to 16\% protein concentrate diet if necessary, and mineral supplementation during all the year.

It was adopted a 40-60 day controlled breeding season beginning in March and November, with expected parturition concentrated from February to April and from August to September. During the breeding season, the female goats were fed supplemental diet due to the small forage production in this period. The goats in oestrus were identified by teaser (vasectomized) bucks and the breeding was controlled at 12-hour intervals until the goats were fertilized. Male breeders were discarded after three years of age and the females after seven years of age. The animals were also discarded based on infertility, maternal inability and diseases.

After data edition, there were 4,313 weights from birth to 196 days of age, based on a 28-day weighing intervals. The body weights were distributed in six classes of age: the first was composed of birth weight, the second by weights recorded at 28 and 56 days of age, the third by weights recorded at 84 and 112 days of age, the fourth by weights at 140 days of age, the fifth by weights at 168 days of age, and the sixth by weights at 196 days of age; two sexes; three types of birth (single, twin and triple) and two weighing station: raining-station from March to July and dry station from August to February. The contemporary groups, which had a minimal of three observations, were formed regarded to year, weighing station and age classes.

The fixed average growth trajectory was modeled using Legendre orthogonal polynomial of order four. Preliminary analyses not considering the random animal effect were undertaken to determine the required polynomial order to model the population trajectory and order higher than four were not statically significant. A total of 12 random regression models were analyzed The random regression model $\mathrm{M}_{\mathrm{ijk}}$ represents a model with polynomial order i for the additive direct genetic effect, order $\mathrm{j}$ for the maternal additive genetic effect, and order $\mathrm{k}$ for animal permanent environment.

The residual variance was considered as heterogeneous and it was modeled by an ordinary polynomial of order three. The heterogeneous residuals variance may be represented as:

$$
\sigma_{j}^{2}=\sigma_{0}^{2}\left(1+\sum_{r=1}^{m} \beta_{r}\left(a_{i j}^{*}\right)^{r}\right),
$$

in which $\sigma^{2}$ = residual variance at age $\mathrm{j}, \sigma^{2}{ }_{0}=$ intercept variance, $\beta_{\mathrm{r}}=$ regression coefficients of the variance function and $\mathrm{a}^{*}{ }_{\mathrm{ij}}=$ age at which measurements were recorded. 
The statistical model used in the analyses can be expressed as:

$$
y_{i j}=F_{i j}+\sum_{m=0}^{k \beta-1} \beta_{m} \phi_{m}+\sum_{m=0}^{k a=3} \alpha_{i m} \phi_{m}+\sum_{m=0}^{k m=3} \gamma_{i m} \phi_{m}+\sum_{m=0}^{k c=3} \delta_{i m} \phi_{m}+\xi_{i j} ;
$$

in which yij= weight $\mathrm{j}$ of goat $\mathrm{i} ; \phi_{\mathrm{m}}=$ legendre polynomial function $\mathrm{m}$ of the standardized age $(-1 \mathrm{a}+1) ; \mathrm{F}_{\mathrm{ij}}=$ fixed effects included in the model (contemporary group, sex, birth type and linear covariate of age of breeder at birth of progeny, the quadratic effect was not included in the model because it was not significant in preliminary analyses, $\beta m=$ regression coefficient $m$ of the weight on Legendre polynomial represented by a cubic function to model the average population trajectory; $\alpha_{i m}, \gamma_{i m}$ and $\delta_{i m}=$ random regression coefficients for the direct additive genetic, maternal additive and animal permanent environment, varying from 2 to 7 degrees to determine the most adequate order to model each random effect, and $\varepsilon_{i j}=$ residual random effect.

In matrix notation the model and assumptions can be represented as:

$$
\begin{aligned}
& \mathrm{y}=\mathrm{Xb}+\mathrm{Z}_{1} \mathrm{a}+\mathrm{Z}_{2} \mathrm{~g}+\mathrm{Wd}+\mathrm{e}, \text { and } \\
& \qquad\left(\begin{array}{c}
y \\
\alpha \\
\delta \\
\varepsilon
\end{array}\right)=\left(\begin{array}{c}
X \beta \\
0 \\
0 \\
0 \\
0
\end{array}\right) e\left\{\begin{array}{l}
\operatorname{Var}(\alpha)=\mathrm{K}_{\mathrm{a}} \otimes \mathrm{A}, \\
\operatorname{Var}(\gamma)=\mathrm{K}_{\mathrm{m}} \otimes \mathrm{A}, \\
\operatorname{Var}(\delta)=\mathrm{K}_{\mathrm{c}} \otimes \mathrm{I}, \\
\operatorname{Var}(\varepsilon)=\mathrm{R} ;
\end{array}\right.
\end{aligned}
$$

in which: $y=$ vector of observation; $\beta$ = fixed effect vector including $\mathrm{F}_{\mathrm{ij}}$ e $\beta_{\mathrm{m}} ; \alpha=$ random vector of the regression coefficient of the additive genetic effect; $\gamma=$ random maternal additive genetic coefficients vector; $\delta=$ vector of permanent environment coefficient; $\mathrm{X}, \mathrm{Z}_{1}, \mathrm{Z}_{2}, \mathrm{~W}=$ corresponding design matrices; and $\varepsilon=$ residual vector. $\mathrm{K}_{\mathrm{a}}, \mathrm{K}_{\mathrm{m}}$ and $\mathrm{K}_{\mathrm{c}}$ = variance and covariance among random regression coefficients for the additive genetic, maternal and permanent environment coefficients; $\mathrm{R}$ = residual variance matrix; A = relationship coefficient; $\mathrm{I}$ = identity matrix; $\otimes=$ kroenecker product. The covariance between additive genetic and maternal effect was considered equal to zero. The variance covariance components between random regression coefficients were estimated by restricted maximum likelihood methodology (REML) using the DXMRR option of the software DFREML (Meyer, 1998), by the free derivative algorithm to maximize the Log of the likelihood function.

The models were initially compared by the change in the logarithm function of the maximum likelihood function ( $\log L)$, the likelihood ratio test according to the following expression LRTij= $2 \log \mathrm{Li}-2 \log \mathrm{Lj}$, in which $\log \mathrm{Li}=$ maximum of the likelihood function for the full model $i$ and $\log \mathrm{Lj}=$ the maximum of the likelihood function for the reduced model $\mathrm{j}$. The obtained estimates were compared to the $\chi^{2}$ table value for $\mathrm{d}$ degrees of freedom at the significance level of $1 \%$, in which $d$ is the difference between the number of estimated parameters for the full and reduced models, respectively. The likelihood ratio test allows the comparison of nested models only and tends to favor models with higher number of parameters. Information criterion of Akaike and Bayesian information criterion tests were also used in the comparison of the models. The information criterion of Akaike can be used to compare models with the same set of fixed effects but with different variance structure. The test considers the best model the one with the lowest information criterion of Akaike value. The Bayesian information criterion test penalizes more models with higher number of parameter in comparison to information criterion of Akaike in such a way the two tests may lead to different results. The values of the information criterion of Akaike (IAC) and Bayesian information criterion (BIC) are obtained as follows:

IAC $=-2 \ln L+2 p$ and $B I C=-2 \ln L+p \ln (N-r(X))$; in which: $\mathrm{p}=$ number of estimated parameter, $\mathrm{N}=$ total number of observation and $r(X)$ is the rank of the fixed effect matrix. Lower values of IAC and BIC correspond to better goodness of fit of the model. Besides these tests, the estimated parameters for each model were compared to evaluate changes in function of the random effect fitted. Genetic values were predicted for birth weight, weights at 112 and 196 days of age to evaluate the ranking of genetic values of animals predicted by different models.

\section{Results and Discussion}

Several analyses with different models to fit growth trajectory using Legendre polynomials function were evaluated to establish a parsimonious model to adequately describe the growth trajectory with moderate number of parameters.

Firstly, model M111 was used in which all the polynomials fitted only the intercept (Table 1). The model included the additive genetic direct and maternal effects, and the animal permanent environment effects. The residual variances were modeled by a quadratic function using ordinary polynomial. The Log $\mathrm{L}$ value was significantly lower for model M111 than for all other models. The information criterion of Akaike and Bayesian information criterion values were the worst for this model. The results suggested that the repeatability model (M111) was inadequate to fit the data. Similar results were observed by Sakaguti et al. (2003) and Arango et al. (2004). The goodness 
Table 1 - Evaluation criteria for the analyzed models

\begin{tabular}{|c|c|c|c|c|c|}
\hline Model $^{1}$ & $\begin{array}{c}\text { Number of } \\
\text { parameters(NP) }\end{array}$ & $\begin{array}{l}\text { Logarithm of likelihood } \\
\text { function }(\text { LOG L })^{2}\end{array}$ & $\begin{array}{l}\text { Information criterion } \\
\text { of Akaike (IAC) })^{2}\end{array}$ & $\begin{array}{l}\text { Bayesian information } \\
\text { criterion }(\mathrm{BIC})^{2}\end{array}$ & $\begin{array}{l}\text { Likelihood ratio } \\
\text { test }(\mathrm{LRT})^{2}\end{array}$ \\
\hline 1 - M111 & 05 & -989.07 & $1,902.14$ & $1,755.97$ & $1,630.58^{*}$ \\
\hline $3-$ M333 & 20 & -59.60 & 73.21 & 22.58 & $56.04 *$ \\
\hline 4 - M334 & 24 & -31.58 & 25.15 & 0.0 & $13.72 *$ \\
\hline $5-\mathrm{M} 434$ & 28 & -24.72 & 19.44 & 19.77 & 2.18 \\
\hline $6-$ M335 & 29 & -25.81 & 23.61 & 30.31 & 8.0 \\
\hline 7 - M444 & 32 & -21.81 & 21.63 & 47.43 & 4.24 \\
\hline $8-M 534$ & 33 & -19.69 & 19.38 & 51.55 & $17.32 *$ \\
\hline $9-$ M336 & 35 & -11.03 & 6.05 & 50.96 & 10.3 \\
\hline $10-$ M346 & 39 & -5.88 & 3.76 & 74.15 & 1.32 \\
\hline $11-$ M337 & 42 & -5.22 & 8.43 & 97.93 & $10.44^{*}$ \\
\hline $12-$ M446 & 43 & 0.0 & 0.0 & 95.87 & \\
\hline
\end{tabular}

${ }^{1}$ Fitting order for additive direct, additive maternal and animal permanent environment.

2 Values expressed as deviation of the best value. ${ }^{*}(\mathrm{P}<0.01)$

of fit increased as the order of the polynomial changed from 1 to 3 inasmuch as these models resulted in higher Log $\mathrm{L}$ value and smaller information criterion of Akaike and Bayesian information criterion values.

According to Log L, the higher order of fit for the effects resulted in larger Log $\mathrm{L}$ values and smaller information criterion of Akaike and Bayesian information criterion values suggesting the model with higher number of parameter (M446 with 43 parameters to be estimated) for direct additive genetic and genetic maternal; animal permanent environment resulted in better goodness of fit. Information criterion of Akaike and Bayesian information criterion showed similar results, which suggests that the model M446 would be most adequate to model genetic curves and permanent effect in this Anglo Nubian herd. However, Bayesian information criterion values suggest that a more parsimonious model, M334, for additive, maternal and animal permanent environment, respectively, were sufficient to model the changes in variances according to ages. As a result of high penalties imposed by Bayesian information criterion, the best suggested Bayesian information criterion model for changes in variances of growth traits in function of age was different of the models suggested by the information criterion of Akaike Log L criterion.

Fischer et al. (2004) observed that model with $\mathrm{k}=3233$ showed the best results based on all the criteria used ( $\log \mathrm{L}$, AIC and BIC) for additive direct, maternal and animal and dam permanent environments. Sarmento et al. (2010), comparing several fitting order for additive genetic, maternal and animal and dam permanent environment effects, respectively, showed that the model M3353, suggested by BIC criterion, was the most adequate to model variances of the analyzed effects.
Jafferézic \& Pletcher (2000), when comparing a set of random regression models to analyze lactation curves, showed that the best model based on likelihood criterion to estimate genetic variances was completely different from those obtained using an unstructured model. The authors concluded that likelihood criterion is not the most adequate for the selection of models. These results show the difficulty in defining criteria for the selection of models to describe growth.

The estimated variances for models M334 and M446 (Figure 1) showed similar behavior. The direct genetic additive variances were of low magnitude at birth and tended to increase until 140 days of age and were similar until 112 days of age for both models. The model M334 described a smoother curve between 112 and 196 days of age, with a slight tendency of decrease at the end of the curve.

Albuquerque \& Meyer (2001) described increasing direct genetic variance estimates during the studied growth period with a more remarkable increase at the end of the period. Increasing direct additive genetic variance during the entire growth period was also related by Lewis \& Brotherstone (2002), Fischer et al. (2004) and Sarmento et al. (2010).

The genetic maternal variance estimate (Figure 1) was very small until 56 days of age and showed an increase from this point to the end of the growth interval. The genetic maternal variances estimated by both models were similar and showed an increasing behavior during the period tested. The smallest values were observed at the beginning and the largest at the end of the growth period, suggesting a remarkable genetic maternal influence on the total variance at the end of the growth period. The variance estimate at the beginning of the growth period is approximately equal to zero, which is not coherent with the expected effect. This might have occurred because the maternal permanent 
environment was not considered in the model, resulting in a possible confusion with the additive genetic maternal effect. According to Meyer (1992), there are evidences that great part of the variance of the maternal effect is considered by including in the model only the maternal additive genetic effect. The partition of variance in maternal genetic and maternal permanent effects in collected records is very difficult even in simple univariate model analyses.

Fisher et al. (2004) showed that the estimated genetic additive maternal variances are constant until 200 days of age. In beef cattle, Valente et al. (2008) observed very low maternal additive genetic variance until 90 days of age, with a remarkable increase until 250 days of age. According to this author, this behavior has no biological basis and can might be explained by the random regression model artifacts.
The estimates of the animal permanent environment variance showed continuous and accelerated increase from birth to 196 days of age (Figure 1). As observed for the genetic variances, the estimated trajectories for both models were similar, although all the estimates from model M334 were smaller than those from model M446. Similar behavior for estimates of permanent environment was reported by Sarmento et al. (2010) and Valente etal. (2008). This estimated behavior is probably a consequence of the accumulative character of this effect (Schaeffer, 2001).

The phenotypic variance estimates (Figure 1) from models M334 and M446 varied from 0.74 to 14.38 and were very similar for both models. The phenotypic variance for both models showed an accelerated increase until 140 days of age and from this point on, it showed a decreased growth.
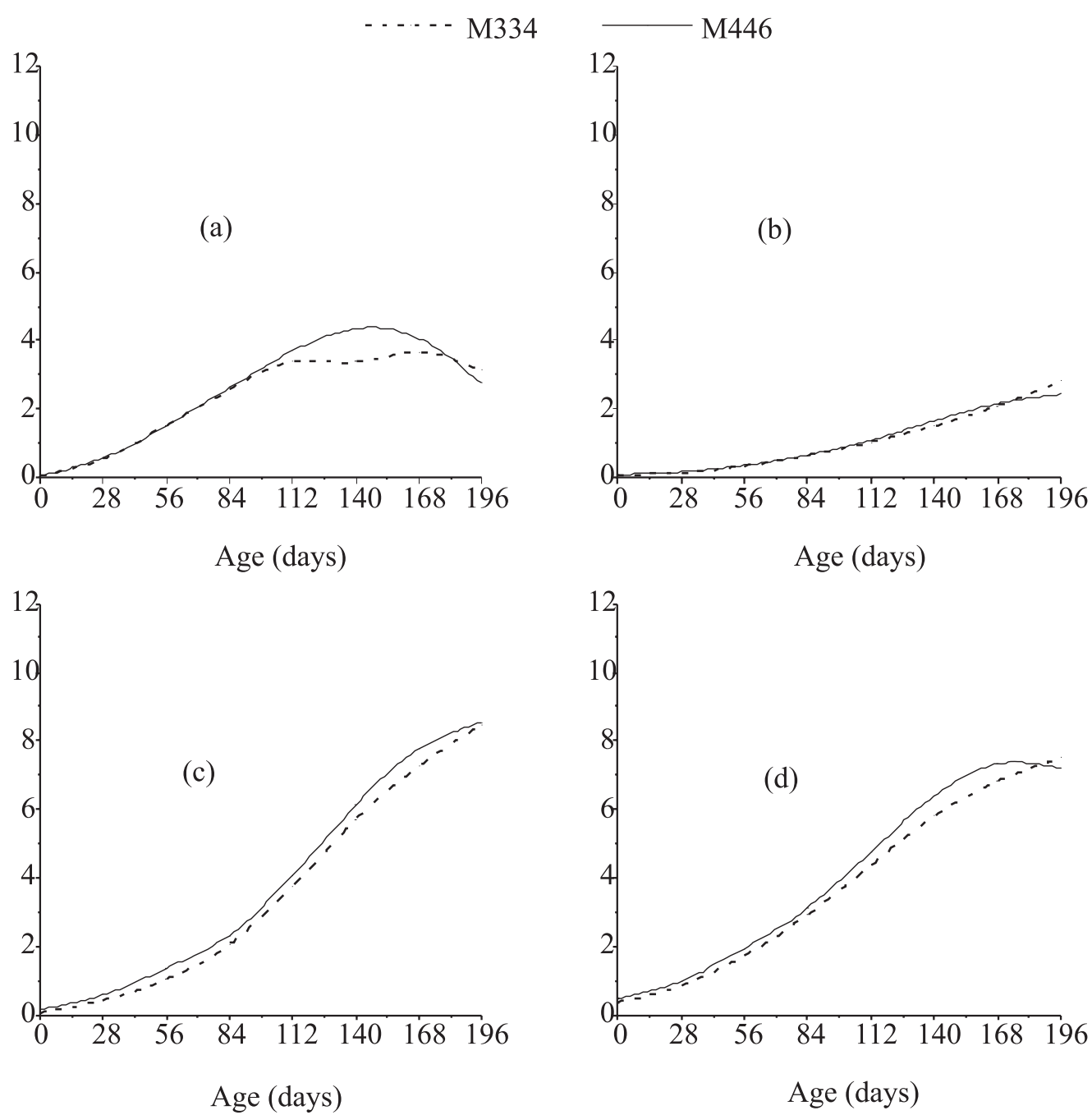

Figure 1 - Direct additive genetic variance components (a), maternal genetic (b), animal permanent environment (c) and phenotypic divided by 2 for models M334 e M446. 
It was also observed that from 28 to 168 days of age, the trajectory described by model M334 was a little shorter than the one described by model M446 resulting in a smooth curve. Fischer et al. (2004) observed an increasing in the phenotypic variance until 300 days of age.

The direct heritability estimates by models M334 e M446 were slightly different at the beginning of the curve. Higher direct heritability estimates (Figure 2) were observed at 56 days of age (0.38 to 0.44 ) for models M446 e M334, respectively. After this age the described curves for both models were similar and decreased until the end of the studied period.

Estimates of maternal heritability were similar for both models during the considered interval of age. Although the differences are smaller, the maternal heritability estimated by model M334 are coherent inasmuch as the maternal heritability estimated by this model showed a slight reduction from birth (0.10) to 56 days of age (0.08), although these values were higher than those for the direct heritability only at birth. Nobre et al. (2003) also reported that the direct heritability tend to be smaller in the age periods when maternal heritability are higher. Therefore, the selection based on maternal ability can result in a performance gain during this age phase higher than the estimated gains from selection of high additive direct genetic values.

The maternal heritability estimates tended to increase from 28 days of age (0.09) until 196 days (0.17). The maximal contribution of the dam to the progeny phenotype, according to the maternal heritability estimates, was observed at 196 days of age. This is not biologically expected for mammals because during the first days of live the progeny totally depends on the mother, mainly on the milk produced by the mother. The results observed in this study are probably because of the management adopted for this herd, in which the progenies are separated from their mothers during the first days of live. Probably, an inadequate feeding management during the initial phase of the progeny growth may also intensify and extend the mother dependency of these animals.

Another hypothesis to explain these results is related to data structure since the number of observations strongly decreases after 112 days of age, which may interfere on the
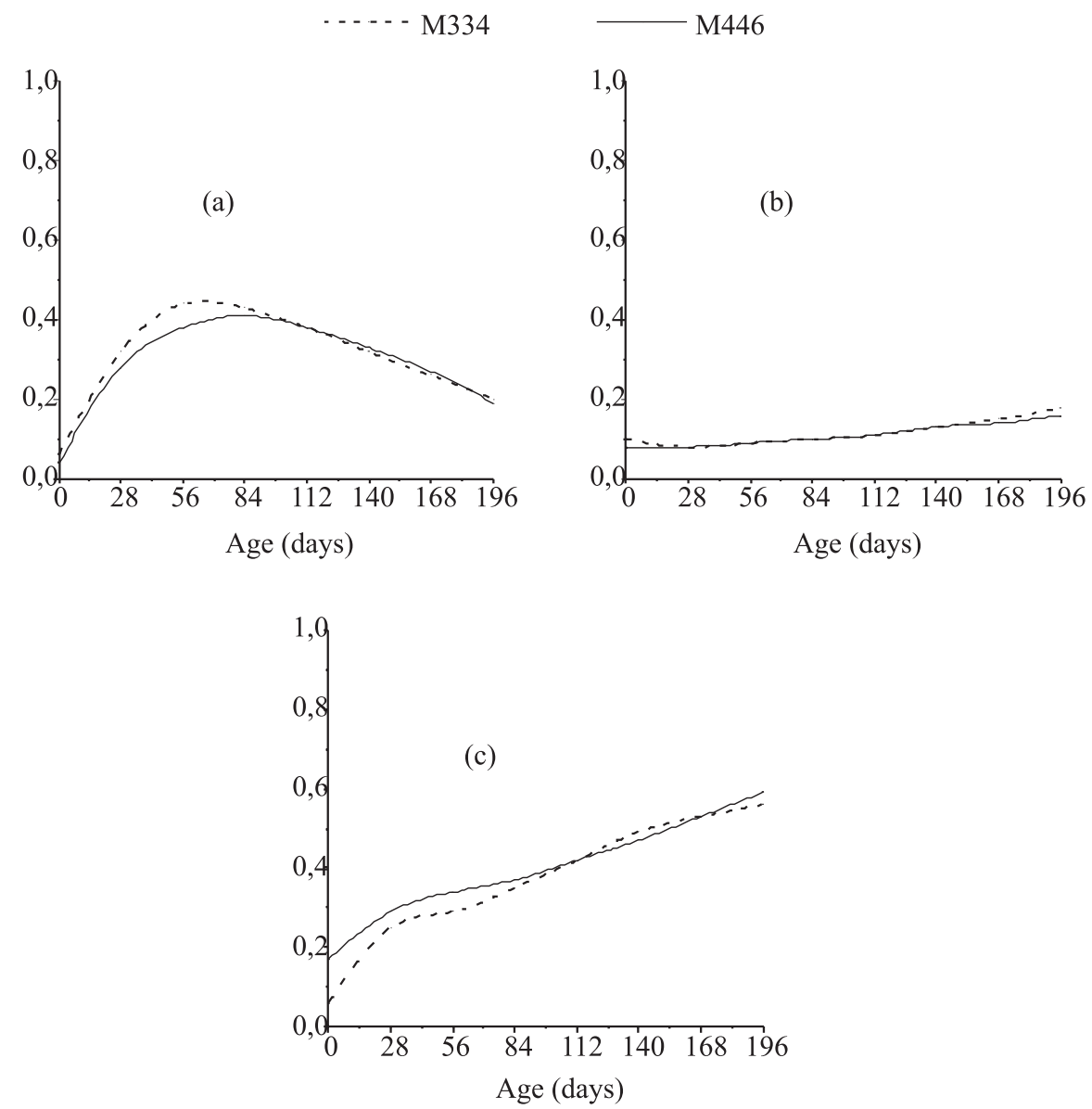

Figure 2 - Direct (a) and maternal (b) heritability and animal permanent environment effect expressed as a proportion of the phenotypic variance (c) for models M334 e M446. 
correct partition of the total variance in the variances attributed to the direct genetic and maternal variances.

The heritability estimates showed values smaller than those estimates reported in literature for meat type goats, most of them obtained by traditional methodology to estimate genetic parameters. Bosso et al. (2007), in a study involving goat breeds in Africa, reported that heritability tends to increase with the age of the animals. Estimates of heritability varied from moderate to high magnitude, varying from 0.50 for birth weight to 0.30 for body weight at 360 days of age. Direct heritability obtained by Snyman \& Olivier (1996) was 0.29 for birth weight and the maternal heritability was smaller for all traits. However, at nine months of age, a strong contribution from the maternal effect for the total variance was observed. For meat type sheep, Sousa et al. (2006) described a decrease in the direct heritability from birth to 112 days of age and the maternal heritability estimates were higher than the direct heritability near the weaning (90 days of age), after which the maternal heritability was approximately equal to zero.

Permanent environment variance estimated as a proportion of the total variance from the selected models (Figure 2) rapidly increased from birth to 30 days of age and moderately increased until the end of the studied interval. In the initial phase of the growth of the animals, from birth to approximately 100 days of age, the variance estimates obtained from model M446 were slightly higher than those from model M334, after which estimates from both models were similar. The results obtained in the present study are similar to those reported by Fischer et al. (2004).

In general, the genetic correlation between birth weight and weights at different ages varied from moderate to high, varying from 0.28 to approximately one for model M334 and from 0.29 to approximately one for model M446 (Figure 3) showing a small difference between the two models. Overall, the correlations tended to decrease as the number of days between the two traits increased. The increase in the order from 3 to 4 resulted in some tide in the surface of the direct and maternal surfaces. Several authors report problems in modeling covariance in the initial and final periods of the growth (Brotherstone et al., 2000; Sarmento et al., 2010). Small numbers of observations for the extreme ages, distance of the average and over parameterized models are reported as possible causes of these problems.

Maternal genetic correlation estimates between birth weight and weights at standard ages varied from low to moderate size. The correlation between birth weight and weights at 28 and 56 days of age were 0.69 and 0.41 for model M334 and 0.59 and 0.39 for model M446, respectively. These correlations decreased with the increase of the age distance of measurements, as expected. Between pairs of ages (84,
112, 140, 168 and 196 days) the estimated correlations varied from 0.88 to 1.0 . The magnitude of these correlations suggests the maternal effects at different ages are controlled by the same genes. Sarmento et al. (2010) reported the sizes of these correlations varying from 0.38 to approximately 1.0 . The maternal genetic correlations varied from 0.60 to 1.0 between measurements of the trait measured at different ages of Santa Inês sheep.

Animal permanent environment correlations were low, mainly among birth weight and weights measured close to 56 days of age, reaching values equal to zero for the correlation between birth weight and weight at 196 days of age. The correlations estimated by model M334 (0.12 - 0.98) were slightly higher than those estimated by model M446 (0.07 -0.93). Dias et al. (2006) reported low correlations for animal permanent environment correlation between birth weight and weights at standard ages (240, 365 and 550 days of age) for beef cattle of Tabapuã breed: $0.25,0.26,0.09$, respectively.

Significant changes in the magnitude of the predicted breeding values and in the ranking of breeding values based on different model of analyses were observed. Thus, the genetic breeding values of the animals for body weight at 112 days of age obtained with the average genetic curve of growth fitted by using a cubic function were ranked (Table 2).

The results suggested that the model highly changed the magnitude of the genetic values. Although the changes in the genetic value were high, the changes in the ranking of the animal were lower. This may have happened because specific model can promote similar changes in the genetic values of all animals resulting in a small change in the ranking of animals despite the alteration in the magnitude of genetic values.

The correlations between predicted genetic values for birth weight, weights at 112 and 196 days of age based on the selected models were similar and varied from 0.59 to 0.99 (Table 3). The highest value was observed for the correlation between weight at 112 and 196 days of age. This result suggests that selection for body weight at 196 days of age can be efficiently anticipated for 112 days without losses, and resulting in higher genetic gains.

\section{Conclusions}

Legendre polynomial functions of order 3, 3 and 4 for the direct genetic, genetic maternal and animal permanent environment, respectively, can be used to describe changes in the covariance of growth curve of Anglo Nubian goats. The heritability estimates are of moderate magnitude, suggesting that selection for body weight can be recommended for the genetic improvement of goats. 

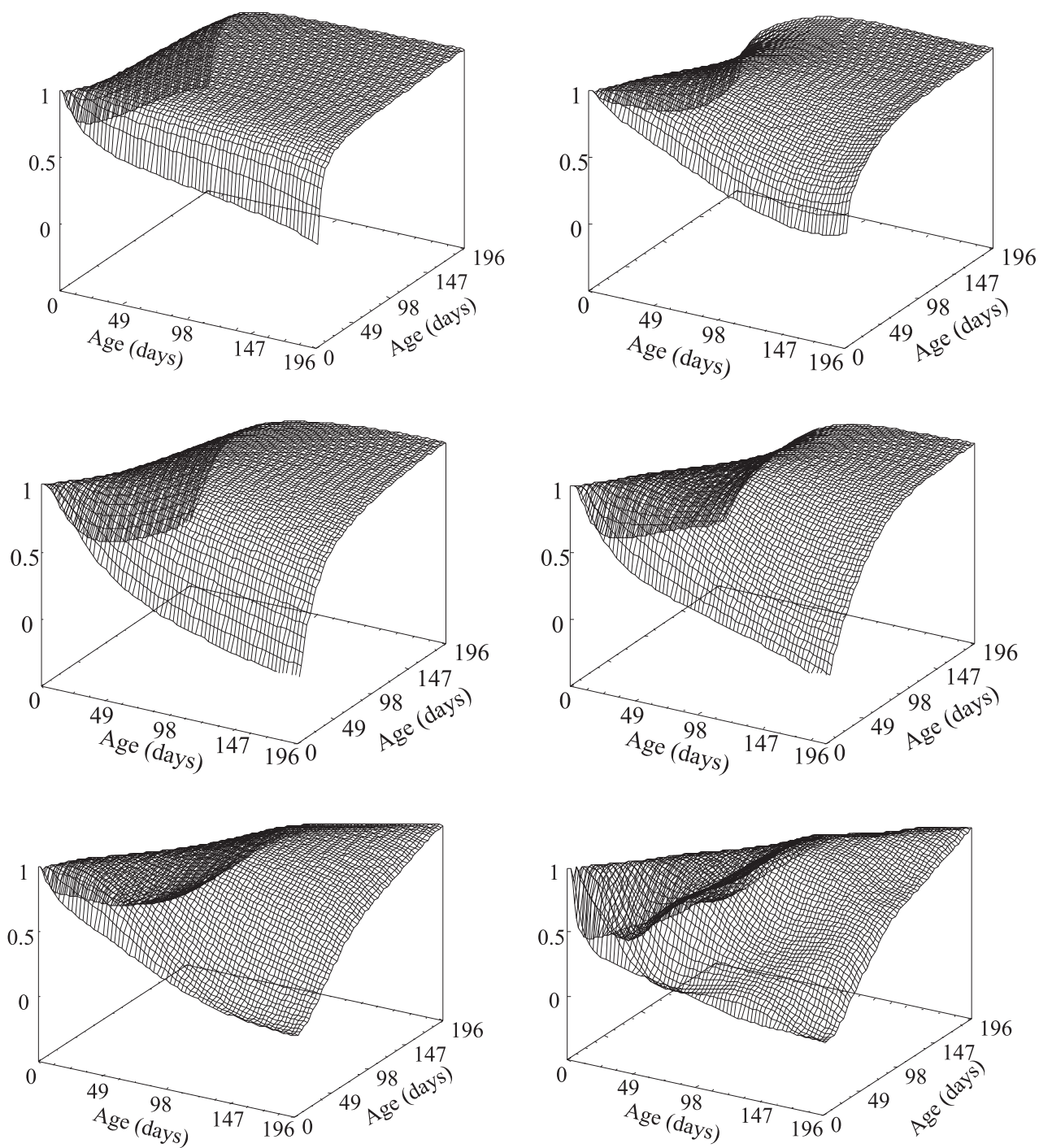

Figure 3 - Genetic correlations (above), maternal correlations (middle) and animal permanent environment correlations (below) estimated by models M334 (left) and M446 (right).

Table 2 - Predicted genetic values of the best eight animals for body weight at 112 days of age based on models M334 and M446

\begin{tabular}{|c|c|c|c|c|c|c|c|}
\hline \multirow[t]{2}{*}{ Animal } & \multicolumn{3}{|c|}{ M334 } & \multirow[t]{2}{*}{ Animal } & \multicolumn{3}{|c|}{ M446 } \\
\hline & Birth & $112^{\text {th }}$ day & $196^{\text {th }}$ day & & Birth & $112^{\text {th }}$ day & $196^{\text {th }}$ day \\
\hline 297 & 0.16 & 4.05 & 3.92 & 297 & 0.13 & 4.59 & 3.97 \\
\hline 834 & 0.12 & 3.93 & 3.87 & 834 & 0.10 & 4.51 & 3.93 \\
\hline 965 & 0.14 & 3.64 & 3.53 & 965 & 0.10 & 4.11 & 3.57 \\
\hline 874 & 0.15 & 3.64 & 3.50 & 966 & 0.09 & 4.10 & 3.58 \\
\hline 1116 & 0.12 & 3.63 & 3.55 & 874 & 0.15 & 3.85 & 3.33 \\
\hline 966 & 0.11 & 3.57 & 3.52 & 976 & 0.16 & 3.78 & 3.23 \\
\hline 976 & 0.21 & 3.52 & 3.26 & 1116 & 0.12 & 3.65 & 3.17 \\
\hline 880 & 0.04 & 3.16 & 3.22 & 1087 & 0.01 & 3.52 & 3.07 \\
\hline
\end{tabular}

Table 3 - Correlation between predicted genetic values by model M334 (above the diagonal) and model M446 (below the diagonal)

\begin{tabular}{lccc}
\hline Trait & Birth weight & Weight at 112 days of age & Weight at 196 days of age \\
\hline Birth weight & - & 0.6079 & 0.5107 \\
Weight at 112 days of age & 0.5452 & - & 0.9918 \\
Weight at 196 days of age & 0.5162 & 0.9991 & - \\
\hline
\end{tabular}




\section{Acknowledgments}

The authors thank Empresa Estadual de Pesquisa Agropecuária da Paraíba (EMEPA - PB) for the data used in the analyses of the thesis of the first author and this scientific paper.

\section{References}

ALBUQUERQUE, L.G.; MEYER, K. Estimates of covariance functions for growth from birth to 630 days of age in Nelore cattle. Journal of Animal Science, v.79, n.11, p.2776-2789, 2001.

ALBUQUERQUE, L.G.; MEYER, K. Estimates of covariance functions for growth of Nelore cattle applying a parametric correlation structure to model within-animal correlations. Livestock Production Science, v.93, n.3, p.213-222, 2005.

ARANGO, J.A.; CUNDIFF, L.V.; VAN VLECK, L.D. Covariance functions and random regression models for cow weight in beef cattle. Journal of Animal Science, v.82, n.1, p.54-67, 2004.

BOSSO, N.A.; CISSÉ, M.F.; VAN der WAAIJ, E.H. et al. Genetic and phenotypic parameters of body weight in west African Dwarf goat and Djallonké sheep. Small Ruminant Research, v.67, n.2, p.271-278, 2007.

BROTHERSTONE, S.; WHITE, I.M.S.; MEYER, K. Genetic modeling of daily milk yield using orthogonal polynomials and parametric curves. Animal Science, v.70, p.407-415, 2000.

DIAS, L.T.; ALBUQUERQUE, L.G.; TONHATI, H. et al. Estimação de parâmetros genéticos para peso do nascimento aos 550 dias de idade para animais da raça Tabapuã utilizando-se modelos de regressão aleatória. Revista Brasileira de Zootecnia, v.35, n.5, p.1915-1925, 2006.

FISCHER, T.M.; VAN der WERF, J.H.J.; BANKS, R.G. et al. Description of Lamb growth using random regression on field data. Livestock Production Science, v.89, n.2 p.175-185, 2004.

HENDERSON JR., C.R. Analysis of covariance in the mixed model: higher-level, nonhomogeneous and random regression. Biometrics, v.38, n.9, p.623-640, 1982.

JAFFRÉZIC, F; PLETCHER, S.D. Statistical models for estimating the genetic basis of measures and other function-valued traits. Genetics, v.156, n.2, p.913-922, 2000.

KIRKPATRICK, M.; HECKMAN, N.A quantitative genetic model for growth, shape and other infinite-dimensional characters. Journal of Mathematical Biology, v.27, n.4, p.429-450, 1989.

KIRKPATRICK, M.; LOFSVOLD, D.; BULMER, M. Analysis of the inheritance, selection and evolution of growth trajectories. Genetics, v.124, n.3, p.979-993, 1990.
LEWIS, R.M.; BROTHERSTONE, S. A genetic evaluation of growth in sheep using random regression techniques. Animal Science, v.74, n.1, p.63-70, 2002.

MEYER, K. Bias and sampling covariances of estimates of variance components due to maternal effects. Genetics Selection Evolution, v.24, n.6, p.487-509, 1992.

MEYER, K. "DXMRR” - a program to estimate covariance functions for longitudinal data by restricted maximum likelihood. In: WORLD CONGRESS ON GENETICS APPLIED TO LIVESTOCK PRODUCTION, 6., 1998, Armidale. Proceedings... Armidale: [1998] (CD-ROM).

NOBRE, P.R.C.; MISZTAL, I.; TSURUTA, S. et al. Analyses of growth curves of Nellore cattle by multiple-trait and random regression models. Journal of Animal Science, v.81, n.4, p.918-926, 2003.

SAKAGUTI, E.S.; SILVA, M.A.; QUAAS, R.L. Avaliação do crescimento de bovinos jovens da raça Tabapuã, por meio de análise de funções de covariância. Revista Brasileira de Zootecnia, v.32, n.4, p.864-874, 2003.

SANTORO, K.R.; BARBOSA, S.B.P.; SANTOS, E.S. et al. Uso de funções de covariância na descrição do crescimento de bovinos Nelore criados no Estado de Pernambuco. Revista Brasileira de Zootecnia, v.34, n.6, p.2290-2297, 2005.

SARMENTO, J.L.R.; TORRES, R.A.; PEREIRA, C.S. et al. Avaliação genética de características de crescimento de ovinos Santa Inês utilizando modelos de regressão aleatória. Arquivo Brasileiro de Medicina Veterinária e Zootecnia, v.58, n.1, p.68-77, 2006.

SARMENTO, J.L.R.; TORRES, R.A.; LÔBO, R.N.B. et al. Modelos de regressão aleatória na avaliação genética do crescimento de ovinos da raça Santa Inês. Revista Brasileira de Zootecnia, v.39, n.8, p.1723-1732, 2010.

SCHAEFFER, L.R. [2001]. Random regression. Disponível em: $<$ http://www.aps.uoguelph.ca/ Irs/ANSC637/LRS14> Acesso em: 15/1/2006.

SNYMAN, M.A.; OLIVIER, J.J. Genetic parameters for body weight, fleece weight and fibre diameter in South African Angora goats. Livestock Production Science, v.47, n.1, p.1-6, 1996.

SOUSA, J.E.R.; OLIVEIRA, S.M.P.; LIMA, F.A.M. et al. Efeitos genéticos e de ambiente para características de crescimento em ovinos Santa Inês no Estado do Ceará. Revista Ciência Agronômica, v.37, n.3, p.364-368, 2006.

SOUSA, J.E.R.; SILVA, M.A.; SARMENTO, J.L.R. et al. Homogeneidade e heterogeneidade de variância residual em modelos de regressão aleatória sobre o crescimento de caprinos Anglo-Nubianos. Pesquisa Agropecuária Brasileira, v.43, p.1725-1732, 2008.

VALENTE, B.D.; SILVA, M.A.; SILVA, L.O.C. et al. Estruturas de covariância de peso em função da idade de animais Nelore. Arquivo Brasileiro de Medicina Veterinária e Zootecnia, v.60, p.389-400, 2008. 